\title{
The Sociology of Agriculture in Transition: The Political Economy of Agriculture After Biotechnology
}

\author{
Gabriela Pechlaner, Ph.D.
}

\begin{abstract}
In 2007, a global food crisis brought the topic of agriculture back into the public eye, and retriggered debates about the ability of agricultural industrialization to feed the world. As a nature-based process and an exception to capitalist industrialization, agriculture trends are difficult to assess. One of the more productive attempts to do so has developed conceptual tools that account for the distinction from typical capital accumulation patterns, notably Goodman, Sorj, and Wilkinson's (1987) classic concepts of "appropriationism" and "substitutionism." Agricultural biotechnologies are testing the limits of even these more refined conceptualizations, as the technologies' associated proprietary framework - including seed saving restrictions, grower contracts, and patent infringement litigation - is reorganizing many traditional agricultural practices. Drawing on case studies in Mississippi, U.S. and Saskatchewan, Canada, this paper argues that these trends suggest a need for a new concept in political economy of agriculture theory, which I term "expropriationism." This concept identifies several aspects of an agricultural reorganization premised on legal means to enhance capital accumulation and on separating corporate ownership from liability. This accumulation strategy has important implications given the high salience that agriculture has for society.
\end{abstract}

Keywords: biotechnology; political economy; genetic modification; GMO; agriculture; patents

Résumé. En 2007, une crise alimentaire mondiale ramena à la une l'agriculture, sujet longtemps négligé, et rouvrit le débat sur l'efficacité de l'industrialisation de l'agriculture pour nourrir le monde. En raison de ses particularités en tant que processus basé sur la nature, il est difficile d'évaluer les tendances du caractère « exceptionnel » de l'agriculture à l'égard de l'industrialisation capitaliste, cependant... Une des tentatives plus fécondes à cet égard fut le développement d'outils conceptuels qui en expliquent la distinction par rapport aux modèles d'accumulation de capital typiques, à savoir les concepts classiques (1987) « d'appropriationisme » et de « substitutionisme » de Goodman, Sorj et Wilkinson. L'avènement de la biotechnologie agricole teste maintenant les 
limites de ces conceptualisations, même des plus perfectionnées, alors que le cadre exclusif associé aux technologies - dont restrictions en matière de semis, contrats pour planteurs et litiges pour contrefaçon de brevets - réorganise un grand nombre de pratiques agricoles traditionnelles. S'inspirant d'études de cas au Mississippi (États-Unis) et en Saskatchewan (Canada), cet article fait valoir que ces tendances reflètent un besoin pour un nouveau concept économique en théorie agricole que j'appelle « expropriationisme ». Ce concept identifie plusieurs aspects d'une réorganisation agricole fondé sur des moyens juridiques permettant d'améliorer l'accumulation de capital et sur la séparation de la propriété et de la responsabilité des personnes morales. Cette stratégie présente d'importantes conséquences compte tenu de la grande prégnance de l'agriculture pour la société.

Mots clés: biotechnologie; l'économie politique; modification génétique; OGM; l'agriculture; brevets

\section{INTRODUCTION}

In 2007, a global food crisis made media headlines and brought the topic of agriculture back into the public eye. Hunger, starvation, and volatile civil unrest in numerous countries occurred in the context of record breaking profits for agrifood corporations. While the triggers of the food crisis were multifold, and included some natural factors, such as droughts, many of them were structural and arose from societal decisions about the role of agriculture and food. Agricultural trade liberalization, agrofuels, and a preference for commercial over subsistence agriculture in developing countries are a few cases in point. This article addresses another structural change affecting agriculture - the introduction of agricultural biotechnologies. More specifically, it addresses the social changes prompted by its proprietary aspects, as "to focus too much on the tools rather than on who is using the tools and for what the tools are being used is to misapprehend the problem" (Kloppenburg 2004:352). The tools of agricultural biotechnology represent an important step in the industrialization of agriculture. There is significant evidence that the legal and regulatory framework associated with the technologies is being used as a new capital accumulation strategy in agriculture, one that expropriates farmers' control over the production process and shifts it to the corporations that are the technologies' developers. Though still evolving, this accumulation strategy has important local and global implications given the high salience that agriculture has for both farmers and for a public concerned with food access. In this context, the role society chooses for the tools of agricultural biotechnology is of central importance. 
Sociology and political economy of agriculture literatures have provided numerous insights into historical capital accumulation trends in agriculture. While some scholars cast agriculture under the broad scope of theoretical perspectives of industrialization, the majority pay heed to the piecemeal accumulation strategies that have accompanied the natural limitations to its full-scale industrialization. In particular, the conceptual tools of appropriationism - the replacement of elements of the production process with industrial ones - and substitutionism - the replacement of agricultural end products with industrial ones - developed by Goodman, Sorj, and Wilkinson (1987) provide an analytical framework through which many historical and current developments in agriculture can be viewed. New agricultural biotechnologies have now brought a significant number of changes to agriculture, however. The blossoming of a network of legal obligations associated with the technologies - prohibitions on seed saving, grower contracts, patents on seeds, and even incentive programs - suggest that important aspects of control over agricultural production may be shifting from agricultural producers to biotechnology developers, with an associated shifting of economic benefit.

While technology-induced change is not new to agriculture, biotechnology's proprietary aspect adds a new component that could instigate a social reorganization of agricultural production. Given this proprietary emphasis, I suggest that a reconceptualization of some of the main tenets of political economy of agriculture scholarship is required. Specifically, the two theoretical concepts of appropriationism and substitutionism identified by Goodman, Sorj, and Wilkinson need to be joined by a third - for which I suggest the term "expropriationism" - to explain new capital accumulation strategies emerging with the advent of agricultural biotechnologies. While the former two terms emphasize accumulation strategies in the spheres of production and processing, the latter is proposed in response to an emerging accumulation strategy based in the network of legal mechanisms associated with the new technologies.

In this article, I will first provide a brief look at sociology and political economy of agriculture literatures regarding capital accumulation in agriculture. Second, I will outline how these literatures apply to the current case of agricultural biotechnology, and where they fall short in explaining developments related to it. I argue that biotechnologies change the way in which capital interacts with agriculture in three ways: they extend the potential for appropriationism and substitutionism; they increase the concentration of input suppliers and processors; and lastly, and perhaps most significantly, their associated proprietary framework initiates a new means of capital accumulation. While the first two are extensions of existing capital accumulation relations in agriculture, the lat- 
ter suggests a new "social" means of capital accumulation, in the manner articulated by Kloppenburg (2004). I will then provide examples of these proprietary elements, drawn from my dissertation research on the extent to which agricultural biotechnologies are facilitating a social reorganization of agricultural production, and what effect this reorganization has on the control farmers have over their production (Pechlaner, 2007). I approach this question comparatively, through two regional case studies - in Saskatchewan, Canada and Mississippi, United States - based around four lawsuits between technology developers and farmers. Last, I will offer some conclusions.

\section{The Industrialization of Agriculture? Conceptual Tools in the Political Economy of Agriculture}

From the classics to contemporary scholarship, political economy of agriculture literature provides numerous insights into historical capital accumulation trends specific to agriculture (see for example, Berlan 1991; Buttel and LaRamee 1991; Friedland 2002; Friedmann 1995; Kautsky 1988 [1899]; Lenin 1964 [1899]; and Thompson and Cowan 1995). The literature has identified trends in industrialization common to agriculture: increased capitalization, concentration of agricultural input suppliers and output purchasers; substitution of independent producers with agribusinesses; increased productivity; the externalization of environmental costs; and the transformation of consumption patterns, among others. In some cases, the parallels with industrialization are drawn to the extent of rejecting agriculture's analytical separation from industry (Goodman and Watts 1994:3).

Many aspects of agriculture deviate from typical capital accumulation patterns because it is a nature-based process. Consequently, while some early political economy of agriculture scholarship found resonance with broader theories of industrialization, it was often at a theoretical cost. Goodman, Sorj, and Wilkinson (1987:145), for example, state that classical attempts to theorize agriculture's position in capitalist development resulted in conceptual distortions and debates inappropriately focused on social relations of production or on the relative benefits of peasant versus capitalist modes of production. Such attempts to drape agriculture in the conceptual cloak of industrialization, they argue, overlook the central problematic of agriculture in capitalist development - its status as a natural process. Where agriculture's natural aspects produce impediments to wholesale industrial transformation, capitalist development finds other ways of incorporating agriculture into its processes; 
notably, by incorporating discrete elements of agrarian production into industrial processes, as will be discussed.

The attempts to draw agriculture into broader theories of industrial restructuring did not stop with classical approaches. Goodman and Watts (1994), identify the concept of "Fordist agriculture" as one such attempt, whereby political economy and regulation theories overstate agriculture's industrialization in an effort to reject its exclusion from industry. They argue that the Fordist agriculture concept fails under empirical assessment, however. While aspects of the processing and input sectors of agriculture demonstrate Fordist tendencies (e.g., high volume, standardized production, and consumption), the concept cannot be sustained with respect to labour at the point of production or to regulation. The significance of such conceptual slippage is not minor. Rather, Goodman and Watts argue that washing over agriculture with the "gloss of Fordism" overlooks important exceptions that need to be explained, and consequently distorts a significant analytical question: "how does the organization of agricultural production and rural space change under different regimes of accumulation and modes of social regulation?" (1994:15). This way of thinking, in contrast, puts agriculture firmly under the umbrella of its broader political economic context, but without creating a forced marriage of industrialization concepts and empirical evidence.

Using a similar method of analytical specificity, Lewontin (2000:95) argues that classical capitalist concentration failed in farming because of the sector's financial and physical characteristics: the ownership of farmland is financially unattractive; labour is hard to control because farms are spatially extensive; economies of scale are limited; and it is largely impossible to reduce the reproduction cycle. Similar to Guppy's (1986) assessment of limited capital penetration in the commercial fishing industry, Lewontin argues that the risks involved in farming - such as weather, disease, and pests - made direct ownership in agriculture unattractive to capital. As a result of these limitations, capital concentrated on the farm inputs and processing sectors in order to capture profits:

The problem for industrial capital, then, has been to wrest control of the choices from the farmers, forcing them into a farming process that uses a package of inputs of maximum value to the producers of those inputs, and tailoring the nature of farm products to match the demands of a few major purchasers of farm outputs who have the power to determine the price paid. Whatever production risks remain are, of course, retained by the farmer. (Lewontin 2000:96)

The concepts of appropriationism and substitutionism developed by Goodman, Sorj, and Wilkinson (1987) provide a means of accounting for 
this piecemeal approach to capital accumulation. While their book is now somewhat empirically dated, the concepts hold their explanatory value for many processes in agriculture today, an indication of their usefulness. The two concepts overcome the aforementioned theoretical errors precisely because they focus on the way in which agriculture is exempted from traditional industrialization. Goodman et al. argue that agriculture, as productivity rooted in the natural processes of the earth, could not be brought wholesale under the control of capital due to the natural limitations of land, time (plant and gestation cycles), and biological processes (photosynthesis). Some of these limitations may be reduced, particularly with the advent of biotechnologies, but to date capital has had to find other means of infiltrating the sector. In response to these natural barriers, it has pursued a piecemeal and discontinuous path of agricultural industrialization through appropriationism and substitutionism.

Appropriationism is the "discontinuous but persistent undermining of discrete elements of the agricultural production process, their transformation into industrial activities, and their re-incorporation into agriculture as inputs" (Goodman et al. 1987:2). By definition, appropriationism occurs in the production sphere of agriculture, where competitive industrial capitals "create sectors of accumulation by re-structuring the inherited 'pre-industrial' rural production process" (1987:8). The trajectories of appropriation therefore depend on the particular history already in place. In 19th century Britain, for example, limited land and plentiful labour led to accumulation strategies based on "high farming" - the replacement of farm-produced animal fodder and manure with purchased oil-seed cake and fertilizer (1987:28). In the United States, on the other hand, land was plentiful, and early appropriationism focused on mechanization and automotive engineering (replacing horses and labour with tractors). Goodman et al. note that as the agronomic problems of mechanization and extensive cultivation became evident in the US, these trajectories merged. Further details of such appropriationist strategies can be found in Goodman et al. and others (for example, Berlan, 1991 on the "power age" and Kloppenburg, 2004 on hybrid technologies).

"Substitutionism" follows a similar process by replacing the products of agriculture with industrial ones. While appropriationism seeks to advance capital accumulation in all facets that can be replaced in agricultural production, substitutionism seeks to replace the agricultural end products, reducing them to industrial inputs for manufactured products. Thus, substitutionism mainly occurs in the processing of agricultural products, and seeks to "interpose mechanized industrial processing and manufacture between the source of field production and final consumption" (Goodman et al. 1987:60). The first substitutions resulted from 
mechanical processes of adding value (e.g., flour milling). Preservation technologies, such as canning and refrigeration, provided another avenue. The advances in distribution capabilities that these technologies brought also facilitated the international division of labour and the vertical integration of capital. Goodman et al. (1987:69) suggest that the production of margarine heralded a qualitatively new form of substitutionism: that of "industrial substitution as product creation." Margarine broke the tight association between agricultural product and processed end product by using cheap industrial raw materials to create a fully industrial substitute for an agricultural product. In consequence, agricultural products "assume[d] the status of industrial inputs, being used interchangeably as determined by cost and technical criteria" (1987:69). From this point on, the power of substitution in accumulation strategies expanded.

Noteworthy here is the historically and naturally contingent process of capital accumulation that appropriationism and substitutionism characterize. Scientific and technological developments are key factors for these processes as they provide new opportunities for capital advancement. State policy and the manner in which capital adjusts to it are also central to these accumulation strategies. For example, the US government's policy institutionalizing production surpluses (which relegated market forces around grains "to a secondary role") ultimately founded a new appropriation strategy as cheap grains supported the expansion of the "livestock feed and fattening industries" (1987:13-14). The role of the state is also central to accumulation strategies as it both supports and regulates technological innovations - such as agricultural biotechnologies. These local level processes reveal the dynamic nature of the resulting agro-industrial complex, in which capital responds to the intersection of history, state policy, and advances in science and technology. Ultimately, these accumulation strategies have functioned to minimize the economic significance of agricultural production and reduce the power of farmers. I will now turn more closely to agricultural biotechnologies.

\section{The Introduction of Agricultural Biotechnologies}

While "biotechnology" has a broad definition, this article is specifically concerned with what many call the "new biotechnologies": those technologies specifically involving genetic manipulation, such as in the creation of transgenics. Commercial release of these genetically modified (GM) crops began in the mid-1990s and adoption has increased astronomically since then. By 2006, the global GM crop production area reached 102 million hectares (James 2006). While the bulk of this adop- 
tion occurs in just six countries, the United States is by far the leader, accounting for $53 \%$ of global production in 2006. Canada is the fourth largest producer, with $6 \%$ of global production (James 2006).

Two traits dominate commercial applications of genetic modification in agricultural crops: herbicide tolerance and insect resistance. Herbicide tolerance (HT) allows crops to survive the application of herbicide, thus allowing weed kill even after crops have emerged. The most common HT crops are Monsanto's Roundup Ready crops. Insect resistant (IR) crops have been genetically modified to incorporate a pesticide, such as Bacillus thuringiensis, into all cells of the plant to protect it from insects. While some innovative genetic modifications are announced with much public fanfare - vitamin A infused "golden rice" to combat blindness in poor countries, for example - to date such innovations have either failed to reach commercialization or remain statistically negligible. Currently, commercialized transgenic traits are: 68\% HT; 19\% IR; and 13\% HT/ IR combined (James 2006). These traits have been applied to a limited number of key agricultural crops - primarily canola, maize, soybeans, and cotton - although applications are increasing. As Arends-Kuenning and Makundi (2000) argue, if the needs of developing countries were considered, one would see traits such as plant hardiness, drought resistance, or salinity tolerant crops for food insecure regions, rather than the same crops and traits evident in developed countries. Therefore, while there are opportunities for socially beneficial agricultural biotechnologies, their development thus far has emphasized that which produces the greatest profit: that is, high-intensity chemical farming in regions already historically producing surpluses. Developing countries can only participate to the degree that they match their agricultures to that of the industrialized world. Nonetheless, in many regions this is already occurring, as biotechnologies extend the agro-industrialization already launched by the Green Revolution (Otero and Pechlaner, 2008). Consequently, while developed countries - the United States, in particular - have driven the adoption of GM crops, it is rapidly increasing in developing countries, which now make up 40\% of global GM crop area. By 2006, GM crop area growth in developing countries increased $21 \%$ from 2005 , compared to 9\% in industrial countries (James 2006).

These are strong indications that biotechnologies will become integral to industrialized agriculture, and, to the extent that they are transformative, they are likely to ultimately be globally transformative. The manner in which the technologies change the relationship between agricultural producers and "capital" (represented by input suppliers and processors, among others) will have significance even beyond the developed countries that are their main promoters. Biotechnologies affect capital's 
relationship to agriculture by increasing the potential for appropriation and substitution; by increasing the linkages between input suppliers, processors, and even retailers; and by facilitating a new capital accumulation through an associated proprietary framework.

Genetic modification greatly expands the number of traits that can be introduced into plants and consequently opens up new possibilities for appropriationism and substitutionism. Goodman et al. (1987) argue that this may even herald a new epoch in appropriation strategies. While industrialization processes have historically worked to "diminish the uncertainties of nature" by rendering agriculture's elements "increasingly measurable and predictable" (Goodman et al. 1987:120), biotechnologies provide opportunities to bring nature even further under industrial control. We can already see evidence of this in the two main genetically modified traits, of which Bacillus thuringiensis (Bt) and Roundup Ready (RR) technologies are cases in point. Prior to the introduction of Bt cotton, for example, farmers needed to check their fields regularly for signs of bollworm infestation, and to act quickly if it occurred. The use of $\mathrm{Bt}$ cotton prevents such an infestation, thus reducing the need for this labour (in exchange for a significant input expense). Similarly, while conventional weed control involves a number of steps, including tilling and repeated, careful herbicide treatments, RR crops reduce this to a quick application of Roundup overtop the growing crop.

Substitutionism is another venue where biotechnologies appear to move food production further under the auspices of bioindustrialization. Early substitutions through chemical engineering are now even further separated from natural processes by industrial microbiology (1987:123). The dramatic changes possible in the food industry from the use of biocatalysts were demonstrated in the case of high fructose corn syrup. The process made possible the substitution of corn (subsidized by surplus policies in the US) and subsequently other grains for cane sugars as sweetener inputs for the processing industry. The result was a dramatic loss for tropical countries (Friedmann 1992). Genetic modification can further improve such biological catalysts, and vastly increase the disaggregation of agricultural products into various substitutable components. Agriculture is thus transformed from the production of crops - such as cotton, potatoes, corn, beans - into the production of inputs - fibres, starches, sugars, oils - for the food processing sector. These inputs are highly exchangeable and can be globally sourced and resourced, according to industry dictates. Genetically modified vanilla, as a substitute for natural vanilla, for example, presents a significant threat to farmers in the limited number of countries that produce the high value crop, such as Madagascar (Suchitra and Surendaranath, 2004; Ramachandra Rao and 
Ravishankar, 2000). Similar research is underway to create substitutes for other developing country crops such as coffee and cocoa.

While never completely distinct processes, biotechnologies provide significant opportunity for heightened convergence of the processes of appropriationism and substitutionism, as crops can be genetically modified with specific traits desired by processors. Over a decade ago, Friedmann (1992:379) argued that if the dominant tendencies were to reach their logical end,

farms would adapt production to demand for raw materials by a small set of transnational corporations ... and in order to meet quality standards would buy inputs and services from (often the same transnational corporations).

This linking is already evident in contract farming, such as poultry production, for example. In the highly vertically integrated poultry sector, farmers are contracted by a company which supplies all the inputs (feed, chicks, and veterinary supplies), requires compliance with specific management procedures, and procures and markets the final product. As agricultural biotechnologies move from the first generation focus on production traits to second generation traits focused on consumer benefits (vitamin or antioxidant enhanced "functional foods," for example), food processors will be even more interested in such linkages.

One consequence of the increased linkage between inputs and end products is that it furthers the corporate concentration already evident in the sectors that bookend agricultural production, decreases farmers' power, and consolidates power over the food supply into an increasingly limited number of hands (for insight into this concentration in the processing sector, see for example Hendrickson and Heffernan, 2007). As this concentration increases in the inputs sector, the potential for alternatives - with respect to input suppliers and to non-GM varieties - decreases according to the dictates of the suppliers. The top ten companies control almost $50 \%$ of the commercial seed market and $84 \%$ of the agrochemicals market (ETC Group 2005b). Given the linkages between these sectors, many of these are the same companies. In 2004, the Monsanto Company accounted for $88 \%$ of the global GM crop area. The company's global market share in key GM crops is also extremely high: $91 \%$ in soybeans, $97 \%$ in maize, $64 \%$ in cotton, and $59 \%$ in canola (ETC Group 2005a, with statistics compiled from the American Society of Agricultural Appraisers and Monsanto). In 2005, the Monsanto Company purchased Seminis, a vegetable seed company, and became the world's largest seed company and instant market leader in global vegetable seeds (for example, Monsanto's global market share is now $31 \%$ in beans, $38 \%$ in cucumbers, and $34 \%$ in hot peppers [2005a]). 


\section{Breaking Proprietary Ground with Agricultural BioteChNOLOGIES}

Even more significant than the above is the effect that the technologies' associated proprietary framework has on capital accumulation strategies. Agricultural biotechnologies have heralded a major breakthrough in privatization strategies around the "seed." The privatization of germplasm provides an excellent exemplar of capital's struggle to accumulate in agriculture - given the natural limitation of the seed's reproducibility - and of the technology's seemingly decisive role in this struggle. Jack Kloppenburg's seminal First the Seed (2004) outlines the capital accumulation patterns that historically evolved in the United States as a result of this natural limitation.

Kloppenburg demonstrates that technology choice is highly dependent on the economic interests involved. He argues that accumulation in US seed production occurred through two (often overlapping) routes one social and one technical. Social routes include legislation designed to protect plant breeders, such as the commercial protection of plant matter afforded under Canada's Plant Breeders Rights Act or the United States' Plant Variety Protection Act. A technical solution for some crops arrived with the advent of hybrid technologies (which prevent commercialgrade regeneration) in the 1930s. According to Kloppenburg, varietal improvement through hybridization instead of open-pollinated varieties (which could be replanted) was a social, not a technological, choice. It was driven by agitation from the seed industry, and is testament to the capacity of private interests to affect the direction of technological advances. Public sector development and disbursement of seed varieties were also impediments to the commercial seed industry. In the US, the privatization trend included a retrenchment of such activities and a progressive reorganization of research for commercial purposes, such as by relegating the public sector to basic research, which the private sector then applies and commercializes. A similar reorganization is now occurring with Canada's agricultural biotechnologies.

Despite these efforts, hybrid technologies and plant breeding legislation have only provided partial solutions to capital accumulation limitations with respect to germplasm. In response to this limitation the biotechnology industry has developed "terminator technology" and lobbied for patents on germplasm. Both routes require the farmer to purchase new seed each season, the former by physically precluding regeneration and the latter by legally doing so. Terminator technology development has already been retracted once due to public outcry over its risks to food security, particularly in developing countries (Vidal 1999). While 
less immediately dramatic, the social route to accumulation evidenced in the technology's associated patents, contracts, and related legalities could have an even greater impact. This impact is sufficiently distinct in character from appropriationism and substitutionism - although there is overlap - that it requires a new concept - "expropriationism." Similar to the conventional meaning of expropriation, expropriationism indicates a seizure of private property by a public body - not directly by the state, in this case, but state-facilitated. Specific to expropriationism, however, is seizure for corporate, rather than public, gain - arguments regarding the public good of private investment in technology development notwithstanding.

I define expropriationism broadly, to capture a range of legal strategies for capital accumulation in agriculture associated with the introduction of biotechnologies. While patents on seeds comprise a key component of expropriationism, the concept actually describes an assemblage of legal mechanisms used in concert to shift the relationship between technology producers and developers to restrict the power of farmers and facilitate a new capital accumulation strategy. The use of social restrictions as a means of accumulation in agriculture is not new. Plant breeders' rights, producer contracts, and even a limited number of plant patents predate the introduction of biotechnologies. What is new, however, is the widespread introduction of an assortment of legal mechanisms associated with a specific technology that is itself becoming widespread, at least in the commercial production of some key crops. In expropriationism, capital is extracted through legal mechanisms, used in novel ways, to facilitate capital accumulation through changes in the systems of power and control. Evidence of these changes can be seen in law, as the technologies' proprietary framework evolves through litigation, and in practice, through the changing relationship of farmers to their production system.

In the following section, I will draw on data from my comparative investigation of the extent to which these technologies are reorganizing agriculture and affecting producer control, highlighting the evidence available to support the proposition that agricultural biotechnologies are facilitating a new form of capital accumulation through legal mechanisms. Mississippi and Saskatchewan are sites of important litigation between technology developers and farmers, providing important insights into the direction in which the proprietary framework for agricultural biotechnologies is developing in the United States and Canada. Data for this research was drawn from court transcripts, reports, and related material, as well as from 35-40 face-to-face, semistructured interviews in each region. Interview respondents were drawn from those directly 
involved in the litigation, as well as from agriculture more broadly (e.g., producers, seed dealers, agriculture organizations, and knowledgeable informants) and were selected either for their specific role (in litigation or as representatives of institutions) or by targeted snowball technique.

\section{Patents, Ownership and Responsibility}

The state plays a central role in expropriationism, overseeing the regulatory environment that facilitates or hinders its expression. In Canada and the United States, the support for expropriationism has been expressed through a strong support of intellectual property (IP) rights and through a demonstrated regulatory reluctance towards articulating limits to these rights with respect to the new category of self-propagating inventions. The granting of general utility patents on plants and/or components of plants was not a forgone conclusion, for example, but required extensive effort on the part of industry, and a supportive national (and international) regulatory environment. Eventually, a corporate friendly proprietary framework was accomplished:

[B]y 1994, within 21 years of the advent of microgenetic engineering technology, the 'bio-industrial complex' had achieved the categorization of biotechnological products and processes within the realms of the patentable at both the US PTO [Patent and Trademark Office] and the EPO [European Patent Office]... and had laid the foundations for the globalization of intellectual property rights.... (McNally and Wheale 1998:310)

The Agreement on Trade Related Aspects of Intellectual Property (TRIPS) of the World Trade Organization (WTO) became the backbone of the international framework for IP protection. With respect to plant life, signatories of the agreement (such as the United States and Canada) needed to either grant patent protection or impose an acceptable sui generis system, such as that provided by the international Union for the Protection of New Varieties of Plants (UPOV). Under UPOV, provisions are available for producers to save seeds for use, although not for resale. This "farmer's exemption" approach to IP protection is more flexible than general utility patents, which require farmers to obtain seed commercially for each planting. The farmer's exemption is contained in UPOV 1978 (of which Canada is a member), but it is left to national prerogative in the 1991 version (of which the United States is a member). While the United States has been fairly unequivocal in its support of plant patents, Canada has demonstrated some ambiguities, particularly in the judiciary. Most notably, in 2002, a Supreme Court ruling on a cancer prone "oncomouse" (designed for cancer research) in Harvard College $v$. 
Canada ${ }^{1}$ (Harvard, hereafter) found higher life forms to be unpatentable in Canada. This is in direct contrast to the United States, where a patent was granted on the oncomouse in 1988. In practice, however, transgenic seeds in both countries are currently protected as if patentable.

While Canadian and US support for IP rights in agricultural biotechnology may be important to their national economic strategies, it nonetheless opens the door to significant clashes of rights between farmers and technology developers. If GM seeds are patented inventions, then the reproduction of that invention (such as through farm-saved seed) constitutes patent infringement. Unlike other inventions, however, GM seeds are self-reproducing, and can spread through the environment in numerous ways. This potential transfer of patented genetic material to lands not under patent contract initiates a whole new form of property rights conflict: farmers, who traditionally have had the right to the products of their land, can find themselves in conflict with biotechnology companies, who claim the right to their patented invention, wherever it ends up. The most obvious and dramatic consequence of this conflict of rights has been the rise in litigation between the two parties. Given the proclivity of seed to spread, some conflict of rights is unavoidable. While the state could initiate preemptive legislation to protect farmers from such liability, however, it has demonstrated regulatory reluctance regarding these issues, leaving resolution to the courts.

A number of issues raise particular concerns over this form of conflict resolution, however. Litigation is very expensive, and there is a vast economic imbalance between farmers and a company like Monsanto. With no independent body to oversee such disputes, technology developers collect the evidence, make the accusation, present a settlement offer, and proceed with litigation if it is refused. As few farmers would be keen to engage in such an economically imbalanced battle, concerns have been raised that those accused of patent infringement are pressured to accept settlements, regardless of the merits of their cause. Such concerns are exacerbated by the fact that settlements are accompanied by mandatory nondisclosure agreements, leaving it to outside organizations such as the Centre for Food Safety (CFS) to estimate the amount of conflict. The CFS extrapolated from Monsanto's own reports that by 2006, the company had handled between 2,391 and 4,531 "seed piracy matters" (CFS 2007) in the United States. By 2007, Monsanto had proceeded with these to file 112 lawsuits (CFS 2007). Thus far, only one case has proceeded all the way to the courts in Canada.

1. Harvard College v. Canada (Commissioner of Patents) [2002] 4 S.C.R. 45. 2002 SCC 76 
Even leaving these inequity concerns aside, a practical legal question remains: in the inevitable conflict between IP rights and traditional property rights, where would the line be drawn for what constitutes patent infringement? In Saskatchewan, this exact question faced scrutiny in the case of Monsanto Canada Inc. v. Schmeiser (Schmeiser, hereafter). ${ }^{2}$ In 1998, the Monsanto Company sued canola farmer Percy Schmeiser for patent infringement, over what he claims was the unwanted presence of RR technology in his crops. Among other issues, the case put on trial the validity of Monsanto's patent - particularly given the earlier Supreme Court ruling in Harvard - and whether a farmer could be held liable for patent infringement in the case of unwanted contamination.

Somewhat counterintuitively, considering Harvard, the Supreme Court decision in Schmeiser upheld Monsanto's patent. The means of doing so (analytically separating the patent on the gene from the plant in which it is expressed, and thus not technically granting a patent on a higher life form) finds resonance in legal arguments in the US courts over the "tying" of the seed and the trait. The contentiousness of the issue is reflected in the 5-4 judgment, with Justice Arbour arguing for the minority that the construction of a patent not only must include the commercial interests of the patentee, but must be fair and reasonable to the public, and exclude that which is not explicitly claimed. Arbour argued that Monsanto could not expand its claim beyond what was specified - that is, to the plant - and, further, given that plants were unpatentable according to Harvard, "the public is entitled to rely on the reasonable expectation that unpatentable subject matter falls outside the scope of patent protection and its use does not constitute an infringement." 3 Consequent to the majority ruling on the validity of the patent, Schmeiser was found guilty of having infringed Monsanto's patent. Monsanto was awarded no damages, however, given Schmeiser was not found to have profited. The court found that possession - not "use" of the invention (e.g., by applying Monsanto's herbicide) or intention - was a valid basis for infringement. This ruling hinged on the fact that the Court found that Schmeiser had been aware of the contamination of his crops, and, therefore, did not prevent the presumption of use found in possession. It is unclear how the courts would resolve the issue of an "innocent" infringer, where innocence connotes innocent of knowledge of the presence of the technology.

In 2005, canola was the only GM crop commercially produced in any significant amount in Saskatchewan. Most producers interviewed in

2. Monsanto Canada Inc. v. Schmeiser (2004), [2004], 1 S.C.R. 2004 SCC 34.

3. Monsanto Canada Inc. v. Schmeiser (2004), [2004], 1 S.C.R. 902 at 911, 2004 SCC 34 at 950 . 
Saskatchewan raised little concern that what had happened to Schmeiser could happen to them, in part because there are few conventional canola producers remaining. In 2005, an estimated $92 \%$ of the canola grown in Saskatchewan was herbicide tolerant, with only two of three types being genetically modified, split between Monsanto (with 45\%) and Bayer (with 30-32\%) (Pechlaner, 2007). Those who used the technologies were overwhelmingly in favour of their ability to assist with weed management in an otherwise difficult - but high value - crop. One user's typical perspective of the agronomic benefits was: "One of the reasons I haven't grown canola over the years is weed control problems, and that's been solved by these new technologies" (SK\#14, March 24, 2005). In many respects, GM canola provided ease of management and time savings for farmers who often had to supplement their income with off-farm work. There is, however, little doubt that GM technology will spread when embedded in a prolific crop such as canola, and in the absence of legislation or protocols this could leave farmers in a legally vulnerable position - especially if they try to revert to conventional canola in the future, for reasons which will become apparent in the discussion of Mississippi. The resulting vulnerability is articulated by one producer/seed dealer, who, while not overly supportive of Schmeiser's claims, notes the legally ambiguous position of farmers:

But it would be hard - it is too bad, if you did get accused and you weren't actually using it, because the seed is blowing around all over the place. It may be hard to prove in some cases, although if you have a crop that is $99 \%$ Roundup Ready [referring to Schmeiser], it is hard to argue that I guess. (SK\#03, March 17, 2005)

It is troubling that while the spread of GM technology is virtually assured in certain crops, there is no indication of an associated corporate obligation to remove unwanted technology. Inklings of legal support for this being the prerogative of the company have already surfaced - explicitly in a small claims case between Schmeiser and Monsanto, and implicitly in Schmeiser, with respect to Monsanto's control over its invention. In the face of a benevolent corporation, abuse of this contradiction is unlikely; however, it begs the question whether farmers should have to depend on such benevolence in an equitable distribution of rights and responsibilities.

Further to the unwanted spread issue is the matter of organic crops. Organic production precludes the use of GM germplasm. Consequently, GM contamination could lead to the decertification of an organic producer's crop, with a substantial loss of revenue to the producer. This issue became the subject of litigation in $2002-$ Hoffman v. Monsanto 
Canada Inc. (Hoffman, hereafter) ${ }^{4}$ - when two organic farmers in Saskatchewan (backed by the Saskatchewan Organic Directorate) sued two transgenic technology developers for the loss of their organic canola market. Hoffman has particular salience since the first legal step was an attempt to certify as a class action suit on behalf of all organic producers. Had it been successful, it would have gone a long way to correct the imbalance of power between technology developers and farmers in these disputes. Without it, the imbalance becomes prohibitive, as noted by Terry Zakreski, lawyer for the plaintiffs:

In regard to this case, not being certified would probably spell the end of the litigation in all likelihood. The individuals do not have the wherewithal to pursue it on their own, and they are not likely to get the support they need just to pursue it through actions. It just becomes nonfeasible to do it. There is a major concern about cost. (SK\#01, August 3, 2005)

Complications limited the strength of the Hoffman claim for class action, however. Monsanto's withdrawal of its application for RR wheat, while a victory, left the application hinging on canola, a far less common organic crop..$^{5}$ Ultimately, class action certification in Hoffman was denied. A key reason was the variability among organic producers, the difficulty of determining what they might choose to produce in a given year, and, consequently, what avoiding canola over contamination concerns might have cost them. While the legal imperative to create strict boundaries of the "class" is understandable, the practicalities of achieving such commonality amongst farmers with different crop rotations are prohibitive. Despite the difficulties of certifying as a class, organic farmers are indisputably affected as a group by each new GM crop introduction. One organic farmer articulated the concerns he had over RR wheat thus:

GMO wheat would be really hard because it would take away one of the most - the main organic crops. Once everything is contaminated with that - losing organic canola was a big loss. Losing organic wheat - I'm not sure the farmers could hang on. (SK\#8, March 20, 2005)

When queried about the prospective introduction of a transgenic alfalfa - a crop of great importance in organic production because it fixes nitrogen in the soil - he continued: "they release some of that it could cross-pollinate right across the whole country before anybody

4. Hoffman v. Monsanto Canada Inc. [2005], 7 W.W.R. 665, 2005 SKQB.

5. Monsanto's application for RR wheat faced such widespread and persistent opposition, not the least of which came from wheat growers themselves (on the basis that it would disrupt their European markets), that the company was finally forced to withdraw its application in 2004. 
knew what had happened." As one consequence, "There'd be no organic cattle anymore." For others, it would be a significant loss for their soil. Subsequently, RR alfalfa was approved by the Canadian government in 2005, but is still pending registration for commercialization.

Another important difficulty arose in fitting the novel issue of GM contamination into available actions. The judge found a gap in the relationship between the plaintiffs and the defendants, suggesting that the sale of an item (such as a chainsaw) could not be blamed for the actions of that item (such as damage from a felled tree), and that action would be more suitably directed at the user of the item - the GM farmer. It is important to note here that the issue of ownership was explicitly addressed. The judge found the technology developers' ownership applied to the technology (and thus they could control seed saving), but that it was not ownership with respect to the cultivation and harvesting of the crop (which could be blamed for the "damage," or contamination). It is exactly this ownership without responsibility that the organic producers tried to address through their attempted class action, as expressed by Arnold Taylor, president of the Saskatchewan Organic Directorate:

I mean, they can't have their cake and eat it too, and that's what they are trying to do. They are trying to say we own it, but we only own it for the purposes of the technology use agreement. If it gets into your grain or whatever it's not our fault, the government let us do it. (SK\#6, March 20, 2005)

The plaintiffs in Hoffman were granted leave to appeal, but class action certification was again denied in 2007. In April 2008, they decided against proceeding with individual claims, and the first attempt to address the liability issue in North America reached its conclusion. In short, the small amount of GM liability litigation thus far - in this case, having occurred only in Canada - favours the ownership rights of technology developers without assigning associated liability for that ownership.

\section{Expropriationism on the Farm? Technology Agreements and Farm- saved Seed.}

Another significant form of proprietary change associated with agricultural biotechnologies is found in the technology agreement [TA]. The TA does not accompany all forms of the technology, but is the purview of the largest supplier, Monsanto. Bayer's GM canola was produced using a hybrid variety, making it less amenable to replanting than Monsanto's. Further, Bayer could charge a high price for its patented herbicide, whereas Monsanto's off-patent herbicide faced too much competi- 
tion from generic versions to do the same. Hence Monsanto turned to the TA as a means of generating revenue (charging $\$ 15 /$ acre for canola in Saskatchewan, for example) and stipulating a number of contractual provisions: with some variation, these include a prohibition on farmers replanting the regenerated seed; they must only sell their crop to an approved processor; and they consent to the inspection of their fields for a number of years following their purchase of the product.

While a few farmers interviewed accepted the TA as a necessary means for the company to recoup its investment, many did not, and vociferous objections to its contractual provisions were almost on par with praise for its agronomic features. As one Saskatchewan producer noted, "It's not just about the $\$ 15$ per acre, it's about what the $\$ 15$ represented" (SK\#14, March 24, 2005). Or, more strongly: "[Monsanto wants] to control the product from the time it goes in the ground to the time it goes into the consumer's mouth, and you're just a pawn, you know, their servant really" (SK\#19, August 4, 2005). For some, like the above producer, this objection was sufficient to drive them to another source for herbicide tolerant canola. Many of those interviewed in Saskatchewan nonetheless felt that the trade-off was worth it, and that if they didn't like it they could simply use another system. In Mississippi, however, such alternatives were limited, and heated objection to the TA and associated conditions of the technologies' dissemination were far more pronounced.

The heart of the proprietary framework of the new GM technologies is a prohibition against the use of farm-saved seed, to ensure the profits of technology developers. This prohibition denies farmers an important noncommercial input option. Many farmers consider seed saving an inherent right, and its prohibition has sparked some apparently straightforward infringement lawsuits, with admitted seed saving, such as in the cases of Monsanto Co. v. McFarling (McFarling, hereafter $)^{6}$ and Monsanto Co.v. Scruggs (Scruggs, hereafter) ${ }^{7}$ both initiated in 2000 in Mississippi. These cases expose a number of important control issues related to biotechnologies.

Whereas in the past farmers might choose to purchase new seed on the basis of the qualities of the commercial varieties offered for sale, the seed saving prohibition ensures such a purchase regardless of any newly desirable qualities. The perceived benefits of GM seeds have convinced farmers to accept both this limitation and the high input cost, in much the way they have historically absorbed each cost on the technological treadmill. Good choices in good economic times are different than in hard economic times, however, and the seasonal lag between such times

6. Monsanto Co. v. McFarling. 363 F. 3d. 1336 (Fed. Cir. 2004).

7. Monsanto Co. v. Scruggs. 342. F. Supp. 2d. 568. (N.D. Miss. 2004). 
can create dissonance. During hard times, farm-saved seed allows farmers to lower input costs. Farmers who adopt a GM technology lose this option in the face of future hardship. In Saskatchewan, for example, a killing frost in August 2005 caused huge losses and put many farmers in economic dire straits. In Manitoba in 2005, heavy flooding prevented farmers from seeding their land, leaving them only with volunteer crops from the previous year: those who had previously grown GM canola were legally prevented from using this second generation crop.

These examples of negative impacts of seed-saving restrictions are obscured when the cost of seed makes only a small dent in overall profits. Pfeffer (1992) argues that postulating a mutually beneficial relationship between agribusiness (supplying inputs to maximize farm production) and farmers (supplying other agribusinesses with food for processing, packaging, and distribution) is only true when times are good. By all accounts, the introduction of GM technologies in Mississippi helped provide these good times. The environmental conditions of the south, where heat and humidity increase insect and weed pressures, made GM cotton and soybeans a godsend for many Mississippi producers, and it was frequently touted as the "salvation" of row crop agriculture, particularly in the context of a bollworm infestation one year prior to Bt cotton's introduction. This has greatly affected the degree to which Mississippi farmers have embraced GM technologies despite their more negative conditions of dissemination than in Saskatchewan. However, the immediate economic interests of farmers and agribusiness are opposed according to Pfeffer, which becomes apparent in downturns: then farmers "begin to take actions to improve their economic well-being that oppose, whether intentionally or not, the immediate economic interests of agribusiness" (Pfeffer 1992:6). Using farm-saved seed is one such action. In response, agribusiness used contracts and patents to prohibit this, albeit at the expense of farmers. While such restrictions might seem a fair price for otherwise appreciated technologies, this "price" is proportional to the degree of adoption/dependence and of market capture specific technology providers. Rising seed costs and grower-unfriendly TA provisions are examples of extra burdens that can be imposed through this market capture.

Rising seed prices were evident in both regions, although to a far greater extent in Mississippi. While HT canola seed prices in Saskatchewan had risen sufficiently to be noted by many interviewees, the high value of the crop still made it a profitable choice for most. In all likelihood, rising canola seed prices were kept in check by market competition between the two GM and the one non-GM HT canola option. Producers in Saskatchewan also had a variety of crops they could rotate to should the cost climb irrationally. In Mississippi, however, $96 \%$ of 
cotton and $96 \%$ of soybeans were transgenic (United States Department of Agriculture [USDA], National Agricultural Statistics Service [NASS] 2005 "acreage"). Further, Monsanto virtually monopolized the Mississippi transgenic market. Monsanto's HT and IR genetic varieties were the first ones available in 1996. Bayer CropScience launched a HT cotton in 2004, but by 2005 Monsanto still retained its near monopoly on GM cotton and soybeans.

Ironically, many Mississippi farmers hadn't historically saved seed because it was so cheap, but objection to the seed saving prohibition increased with the rising price of seed. As one farmer stated:

... now, it costs so much, you'd save a lot of money by [saving seed]. Before it just wasn't cost effective. Why not buy good quality seed because it wasn't that expensive anyway. (MS\#6, May 25, 2005)

While strict annual cost comparison is difficult for a number of reasons (e.g., pricing shifts in the transgenic package and various incentive agreements), there is little doubt that seed costs rose dramatically. According to CFS estimates, the cost of cottonseed increased 3.4 fold from 1995 to 2005 (cited in the Organization for Competitive Markets 2007). Many farmers felt this was a response to the elimination of the secondary market of saved seed, which removed a significant source of competition for seed dealers. Expressions of frustration such as the below were typical in Mississippi:

We can't save our seed.... We have no choice, we've got to pay this exorbitant price for the seed. So something's out of kilter there, that they're able to shove that down our throat.... They do a mark up, but that's because they've got something we have to have, and we've no other way of getting it. (MS\#34, GM Producer, June 9, 2005)

As this grower intimates, many farmers were close to technological dependence on GM technologies, and felt they could no longer farm competitively without it. They had no choice but to buy the seed at whatever cost.

The question of whether the prohibition on seed saving was an unreasonable restraint on trade was at issue in McFarling. Monsanto only patented its technology, which it licensed to the dealers, and the prohibition provided an arguably unjustifiable boon for dealers who now catered to a trapped market. Was Monsanto impermissibly broadening the scope of its patent to uncompetitive ends? What was covered by Monsanto's patent: the gene? the seed? The related abstract legal arguments had very practical ramifications for farmers. If only the genetic trait is patented, then farmers could save their seed and simply pay an annual licence fee 
for using the technology. Obviously, the precedent for this was already found in Monsanto's licensing agreements with seed dealers.

Both McFarling and Scruggs raised a number of allegations that Monsanto engaged in "tying" and "bundling" arrangements, and antitrust and patent misuse became important issues to the defence in both cases. The difficulty of comparing annual seed costs is indicative of the number of control issues associated with the dissemination of biotechnologies. Monsanto has created a web of incentive and reward programs that not only affect pricing, but increasingly dictate farmer's production processes. For example, cottonseed used to be sold by the bag, with the technology fee charged per acre. Monsanto charged on a per seed basis, providing an incentive program that capped the cost if farmers used Monsanto's herbicide rather than a generic one. Farmers who planted at a higher rate - as recommended by the state's agricultural extension program - would pay much more if they didn't use Monsanto's herbicide. Policies for replanting rebates - as in the case of a planting failure - were similarly structured to economically motivate farmers to use Monsanto's herbicide. These rules constantly changed, forcing farmers to adjust accordingly. When sharing their perspective on these issues, Mississippi farmers expressed an enormous amount of frustration and anger over the price increases and Monsanto's various incentives and contractual provisions. The overall sentiment towards Monsanto was well summed up by an agricultural expert in soybeans:

[Growers] hate them. You know, the little crap they keep coming along ... they want you to sign contracts, then they want to charge you by the seed for cotton, they just keep changing the rules again.... They got him tied he can't go any other way and he hates that.... They've just got so many little rules. (MS\#20, June 1, 2005)

Earlier versions of the TA contractually obligated farmers to use Monsanto's herbicide, although this was removed from later versions. Nonetheless, despite persuasive arguments in Scruggs regarding the tying of Monsanto's herbicide with its technology, the District Court judge concluded that farmers were under no obligation to use Roundup, as they could choose to use no herbicide at all, an option that makes no economic sense.

The issue of market capture extends to the equity of the grower contract provisions. Two provisions of the TA that significantly disadvantage farmers are the forum selection clause (any disputes were to be adjudicated in Monsanto's home town of Missouri) and the 120 multiplier clause (an infringer is liable for damages equal to 120 times the applicable technology fee). The former greatly increases the cost and hard- 
ship of any litigation, regardless of guilt; the latter would likely bankrupt anyone found guilty of infringement. Both provisions carry a powerful economic threat and were sufficiently detrimental to farmers to make a dissenting judge in McFarling argue that the TA amounted to a contract of adhesion - a contract with take-it-or-leave-it provisions made between parties with unequal bargaining power. Since the HT seeds offered by Monsanto were considered to be far more competitive than non-HT seeds, and farmers could not obtain these seeds from any other source, they were forced to accept the contract regardless of its terms or become uncompetitive. While the 120 multiplier was ultimately struck down in McFarling, the forum selection clause was upheld.

Whether legally contracts of adhesion or not, however, the provisions of the evolving TA obviously disadvantage farmers. Similarly, the pricing, replant policies, and rewards and incentive programs all create a legal web balanced against farmers. To the extent that biotechnologies become necessary to remain competitive, producers are locked in to paying what its suppliers demand and accepting any associated conditions. As high seed costs and restrictive production rules prompt some producers to search for alternatives, the repercussions of a monopolistic market capture become increasingly evident. Where crops are varied, switching crops provides relief. The more limited rotations of Mississippi's cotton and soybean farmers restrict such strategies. In theory, producers could revert to non-GM varieties. In both regions, the question of whether such alternatives were still available depended on a qualification of "alternative." While the public sector is still engaged in basic research, public sector release of varietal improvements in conventional crops with transgenic counterparts has fallen off; improvements are increasingly only available in commercial GM varieties. A farmer's choice in this case is farm GM varieties or use unimproved seed stock. Most interviewees claimed that unimproved seed stocks were not practically viable, as they would have lower yields and/or less disease resistance. As more bluntly stated by one GM producer in Mississippi: "when we look at the alternatives, we don't have any" (MS\#31, June 8, 2005).

McFarling's petition to have the Supreme Court hear these issues was denied in 2008. After the Scruggs' overall arguments that Monsanto was attempting to "cartelize" the seed industry were rejected on Summary Judgement, the Auditor General of Mississippi intervened to lend support to these issues needing to go to trial. Nonetheless, a number of subsequent applications and appeals were denied, including a 2007 application to the Supreme Court. By 2009, in light of a subsequent court decision, the Scruggs petitioned for a reconsideration of the 2004 Summary Judgement decision. Despite no small effort and a limited window 
for future action, Scruggs has also failed to significantly alter the conditions under which agricultural biotechnologies are sold. While these issues can face future challenges, the effect of the web of legal mechanisms ushered in with agricultural biotechnologies appears unambiguous. Farmers adopt GM crops on the basis of an individual cost-benefit assessment, but the associated trade-offs increasingly dictate many aspects of their production process. The road would indeed seem to lead towards Lewontin's "farmer as mere operative" (2000:97). As GM technology is introduced into more and more key crops - GM beets have most recently been commercialized - the narrowing of choices and economic strategies will have an increasingly significant impact on farmers.

\section{Conclusion}

While Goodman, Sorj, and Wilkinson's concepts have provided a strong basis for analyzing capital accumulation strategies in agriculture, they fail to address new strategies associated with the proprietary aspects of biotechnologies. Consequently, I suggest a new concept - "expropriationism" - to address the theoretical gap left by appropriationism and substitutionism's inability to account for these new trends, while remaining true to Goodman et al.'s accounting of agriculture's exceptionalism. This concept identifies several aspects of an agricultural reorganization based on legal means to enhance capital accumulation and separate corporate ownership from liability. This use of legal mechanisms to facilitate accumulation is not unique to agriculture, of course. However, the way it manifests in agriculture - patents reformed to persist through an "invention's" self-replication, liability protocols for unwanted gene spread, and incentive agreements that play on the potential for crop failures to garner herbicide loyalty, as examples - pays tribute to the persistent need to incorporate even nature in this accumulation strategy.

There is, of course, some overlap in the concepts of expropriationism, appropriationism, and substitutionism. The replacement of farm-saved seed with purchased GM technology is another form of appropriationism, for example. Genetic modification technologies have fast-tracked the technological treadmill and facilitated this appropriationism through a legal prohibition on the use of farm-saved seed, however: this legal aspect is distinct from appropriationism in general. Restrictive grower contracts, litigation intimidation, incentive agreements that leave little to choice, and evolving limitations on liability for unwanted spread all indicate other emerging legal strategies to accumulation. The term "expropriationism" seeks to address these changes and to act as a theoretical addendum where political economy explanations fall short. 
It is simply not possible to assess national agricultural change without some acknowledgement of the global context, and their mutually conditioning influence. Historically, North American agriculture has developed squarely in the context of international trade. In the current context of deepening agricultural internationalization, concerns about shifting control over agriculture by legal fiat become extremely urgent, particularly when reproduced on a scale that reaches the world's poorest farmers. The ongoing hunger crisis provides sufficient grounds for questioning public support for such accumulation strategies. While it seems that the path is set for global expropriationism, as Kloppenburg notes, new technologies are not developed and disseminated in a vacuum. There are powerful political and economic forces driving their development, but there are also forces of resistance, both within and outside the legal forum. The abrupt and significant decline in farmer's rights has provided one catalyst for broader civil society response, as have numerous forms of litigation - such as successful US litigation requiring environmental impact assessments for GM alfalfa (Fox, 2007) - which intensifies the pressure on governments. Such sociopolitical forces must be accounted for in any trajectory of the technology's future development.

\section{REFERENCES}

Arends-Kuenning, Mary and Flora Makundi. 2000. Agricultural biotechnology for developing countries. American Behavioral Scientist 44(3):318-350.

Berlan, Jean-Pierre. 1991. The historical roots of the present agricultural crisis. Towards a New Political Economy of Agriculture. Friedland, William H., Lawrence R. Busch, Frederick H. Buttel, and Alan P. Rudy, (Eds), 115136. Boulder: Westview Press.

Buttel, Frederick and Pierre LaRamee. 1991. The 'disappearing middle': a sociological perspective. Towards a New Political Economy of Agriculture. Friedland, William H., Lawrence R. Busch, Frederick H. Buttel, and Alan P. Rudy, (Eds), 151-169. Boulder: Westview Press.

Centre for Food Safety [CFS]. 2007. Monsanto vs. U.S. Farmers: November 2007 Update. Available online: http://www.centerforfoodsafety.org/pubs/ Monsanto\%20November\%202007\%20update.pdf (January 10, 2009).

ETC Group. 2005a. Global Seed Industry Concentration-2005. ETC Group Communique. September/October 2005 Issue \#90. Available online: http://www.mindfully.org/Farm/2005/Global-Seed-Industry6sep05.htm (February 11, 2006).

2005b. Oligopoly, Inc. 2005: Concentration in Corporate Power. ETC Group Communique. December 2005. Issue \#91. Available online: http:// www.etcgroup.org/en/materials/publications.html?pub id=42 (February 11, 2006). 
Fox, Jeffrey. 2007. US courts thwart GM alfalfa and turf grass. Nature Biotechnology. Vol.25(1). Available online: http://www.biology.iupui.edu/biocourses/Biol540/GMOregulationnbt0407-367.pdf (November 23, 2009).

Friedland, William. 2002. Agriculture and rurality: beginning the 'final separation'? Rural Sociology. 67(3): 350-371.

Friedmann, Harriet. 1992. Distance and durability: shaky foundations of the world food economy. Third World Quarterly. 13(2):371-383.

1995. The international political economy of food: A global crisis. International Journal of Health Services 25(3):511-538.

Goodman, David and Micheal Watts. 1994. Reconfiguring the rural or fording the divide? Capitalist restructuring and the global agro-food system. Journal of Peasant Studies. 22(1):1-49.

Goodman, David, Bernardo Sorj, and John Wilkinson. 1987. From Farming to Biotechnology: A Theory of Agro-Industrial Development. Oxford: Basil Blackwell.

Guppy, Neil. 1986. Property rights and changing class formations in the B.C. commercial fishing industry. Studies in Political Economy. 19:59-81.

Hendrickson, M. and W. Heffernan, Dept of Rural Sociology, Missouri. 2007. Concentration of agricultural markets. Available online at: http://civileats.com/wp-content/uploads/2009/05/2007-heffernanreport.pdf Accessed September 20, 2009.

James, Clive. 2006. Global status of commercialized biotech/GM crops: 2006. ISAAA Brief 35. Executive Summary. International Service for the Acquisition of Agricultural Biotechnology Applications [ISAAA]. Available online: http://www.isaaa.org/Resources/publications/briefs/35/ executivesummary/default.html (June 11, 2007).

Kloppenburg, Jack. 2004. First the Seed: Political Economy of Plant Biotechnology, 1492-2000. Second Edition. Madison: The University of Wisconsin Press.

Kautsky, Karl. 1988 [1899]. The Agrarian Question, Volume I. Translated by P. Burgess. London: Zwann Publications.

Lenin, Vladimir. 1964 [1899]. The Development of Capitalism in Russia. Second Revised Edition, Moscow: Progress Publishers.

Lewontin, R.C. 2000. The maturing of capitalist agriculture: farmer as proletarian. In Hungry for Profit. Fred Magdoff, John Bellamy Foster, and Frederick Buttel (eds.), 93-106. New York: Monthly Review Press.

McNally, Ruth and Peter Wheale. 1998. The consequences of modern genetic engineering: patents, 'nomads' and the 'bio-industrial complex. The Social Management of Genetic Engineering. Wheale, Peter, Rene von Schomberg, and Peter Glasner, (eds.), 303-330. Ashgate Publishing.

Organization for Competitive Markets. 2007. OCM opposes Monsanto acquisition of Delta \& Pine. News Release: March 12, 2007. Available online: 
http://www.competitivemarkets.com/ipowerweb/press releases/2007/312Monsanto.htm (May 1, 2008).

Otero, Gerardo and Gabriela Pechlaner. 2008. Latin American agriculture, food and biotechnology: temperate dietary pattern adoption and unsustainability. Chapter 2 in Food for the Few: Neo-Liberal Globalism and the Biotechnology Revolution in Latin America. Gerardo Otero (ed.). University of Texas Press.

Pechlaner, Gabriela. 2007. Beyond the Science of Agricultural Biotechnology: Corporate technology, law, and local control over food production. Ph.D. dissertation. Simon Fraser University. Department of Sociology and Anthropology.

Pfeffer, Max. 1992. Sustainable agriculture in historical perspective. Agriculture and Human Values. 9(4): 4-11.

Ramachandra Rao, S. and G. A. Ravishankar. 2000. Vanilla flavour: production by conventional and biotechnological routes. Journal of the Science of Food and Agriculture 80(3):289-304.

Suchitra, M. and C. Surendaranath. 2004. Kerala Farmers Grow Vanilla for Profit. Down to Earth. Available online: http://www.indiaenvironmentportal. org.in/node/37401 (September 20, 2009).

Thompson, Susan and J. Tadlock Cowan. 1995. Durable food production and consumption in the world-economy. Food and Agrarian Orders in the World-Economy. McMichael, Philip (ed.), 35-54. Westport, Connecticut: Greenwood Press.

USDA, National Agricultural Statistics Service [NASS]. 2005. Acreage. Available online: http://usda.mannlib.cornell.edu/reports/nassr/field/pcp-bba/ acrg0605.pdf (May 23, 2006).

Vidal, John. 1999. World braced for Terminator 2. The Guardian. Available online: http://www.guardian.co.uk/science/1999/oct/06/gm.food2 Wednesday October 6, 1999. (November 23, 2009).

Gabriela Pechlaner is a SSHRC postdoctoral fellow at the Centre for Economic and Social Aspects of Genomics (CESAGEN) at the University of Lancaster. Her dissertation investigated the advent of transgenic crops in agriculture, focusing on changes to control over agricultural production and on the lawsuits that emerged with the new technologies' introduction. She is currently researching the effectiveness and legacy of legal mobilization strategies for resisting agricultural biotechnologies in the United States.

gabepech@telus.net 
